\title{
Inativos da educação: despesa da educação? ${ }^{1}$
}

\author{
Inactive of education: expenditure on education? \\ Inactivos de la educación: ¿gasto de la educación?
}

FÁBIO ARAUJO DE SOUZA

\begin{abstract}
Resumo: Este artigo apresenta os resultados de uma pesquisa que tem como objetivo analisar as despesas com os inativos da educação pagas com recursos da educação nos governos estaduais, no distrital, no federal e nos municipais. Foram analisadas diversas legislações, estudos sobre o tema, processos judiciais dentre outros documentos. A conivência dos órgãos fiscalizadores e o imbróglio legal são indutores dessa despesa persistir na educação. Como resultado se constatou que a maioria dos governos pagam inativo da educação com recursos da educação, embora a inclusão dessa despesa não seja algo consensual e a recomendação do TCU seja de não considerar inativos como despesas da educação.
\end{abstract}

Palavras-chave: Inativos da educação; financiamento da educação; Tribunal de Contas.

Abstract: This article presents the results of a research that aims to analyze the expenditure on the inactive education paid with educational resources in state governments, in the district, in the federal and in the municipalities. Several laws, studies on the subject, judicial proceedings and other documents were analyzed. The connivance of the supervisory bodies and the legal imbroglio induce this expenditure to persist in education. As a result, it was found that most governments pay for inactive education with education resources, although the inclusion of this expenditure is not consensual and the recommendation of the TCU is not to consider inactive as education expenditure.

Keywords: inactive of education; education financing; Court of Auditors.

Resumen: Este artículo presenta los resultados de una investigación que tiene como objetivo analizar los gastos con los inactivos de la educación pagados con recursos de la educación en los gobiernos estatales, distritales, federales y municipales. Se analizaron diversas legislaciones, estudios sobre el tema, procesos judiciales entre otros documentos. La connivencia de los órganos de

1

Agradecimentos: $\mathrm{O}$ autor agradece a contribuição dos pareceristas ad hoc através das sugestões para a melhoria do artigo. Registro, também, o agradecimento ao professor doutor Nicholas Davies pelas correções e sugestões. 
control y el embrollo legal son inductores de este gasto persistir en la educación. Como resultado, se encontró que la mayoría de los gobiernos pagan por la educación inactiva con recursos educativos, aunque la inclusión de este gasto no es consensual y la recomendación del TCU es no considerar la inactividad como gasto en educación.

Palabras clave: inactivos de la educación; financiación de la educación; Tribunal de Cuentas.

\section{INTRODUÇÃO}

Este artigo apresenta os resultados de uma pesquisa que tem como objetivo analisar as despesas com os inativos da educação, pagas com recursos da educação nos governos estaduais, no distrital, no federal e nos municipais. Há muito tempo essa discussão paira sobre o financiamento da educação pública. Parte significativa dos recursos da Manutenção e Desenvolvimento do Ensino (MDE), e até mesmo, da educação é aplicada no pagamento de inativos da educação e, consequentemente, deixa de ser aplicada nas redes de ensino do país. Para fins deste artigo, o conceito de inativos será aplicado para se referir aos aposentados e aos pensionistas.

Neste texto, o termo MDE, quando usado, refere-se ao percentual mínimo de impostos e transferências previstos no artigo 212 da Constituição Federal de 1988 (CF/88), ou o percentual previsto nas Constituições Estaduais ou Lei Orgânica Municipal, quando acima do mínimo previsto na $\mathrm{CF} / 88$, e às despesas previstas no artigo 70 da Lei de Diretrizes e Bases da Educação Nacional (LDB). Já o termo educação reporta-se aos demais recursos, que podem ser aplicados em MDE, mas que não compõem o percentual mínimo, tais como: Salário-Educação, convênios, royalties e participação especial (compensações financeiras para os entes afetados pela exploração de recursos naturais), programas e demais fontes de recursos. Há que se entender que os recursos da MDE estão contidos nos recursos da educação.

As únicas áreas sociais para as quais a $\mathrm{CF} / 88$ determina um percentual mínimo de impostos para ser aplicado por todos os entes federados são a educação e a saúde. Cabe destacar que, com o advento da Emenda Constitucional (EC) 95, aprovada em 2016, a União poderá não cumprir a aplicação dos percentuais mínimos na MDE e na saúde (BRASIL, 2016a).

Embora a despesa com inativos conte com uma fonte própria, baseada na contribuição de empregados e empregadores e nos recursos da seguridade social para financiá-la, muitos governos pagam os inativos da educação com recursos da MDE ou da educação. O efeito disso é que na mesma proporção eles deixam de ser canalizados para a melhoria das redes de ensino. 
Esta pesquisa, portanto, apresentará diversos posicionamentos acerca da questão, além de apresentar dados das finanças federal, estaduais, distrital, municipais sobre a aplicação dos recursos da educação para pagamento dos inativos da educação. Com isso, espera-se contribuir para o debate acerca do tema sob a perspectiva científica que tem compromisso com a distribuição justa dos recursos públicos da educação no país.

\section{OS INATIVOS DA EDUCAÇÃO PÚBLICA: UMA DISCUSSÃO NECESSÁRIA}

O Regime Próprio de Previdência Social (RPPS) foi concebido pela CF/88 por um caráter contributivo e solidário mediante contribuição do respectivo ente público, dos servidores ativos e inativos. O Regime é voltado para os servidores públicos, com regras específicas para militares, da União, dos estados, do Distrito Federal e dos municípios que podem contar, também, com a previdência complementar. A proposta de contrarreforma da previdência, ou seja, medidas regressivas de ajuste dos direitos sociais à lógica neoliberal, cujo objetivo velado era a desconstrução de direitos sociais consolidados, apresentada pelo governo de Fernando Henrique Cardoso foi promulgada e tornou-se a EC 20/1998. A EC tinha como objetivo oculto aprofundar um processo de desmonte da previdência social, prevista originalmente na $\mathrm{CF} / 88$, por meio do controle da dívida pública, da possível estabilização econômica e da confiança dos investidores estrangeiros. As demais mudanças na previdência social, propostas pelos governos Lula da Silva, Dilma Rousseff, Michel Temer e, recentemente, através da Proposta de Emenda à Constituição (PEC) 06/2019, pelo governo Bolsonaro viabilizam a agenda do Banco Mundial e do Fundo Monetário Internacional quanto às mudanças legais na seguridade social brasileira (LOURENÇO; LACAZ; GOULART, 2017).

O RPPS deve ser gerido por uma Unidade Gestora que contará com até $2 \%$ do valor total das remunerações, proventos e pensões dos segurados vinculados ao RPPS, relativo ao exercício financeiro anterior, a título de Taxa de Administração. Nem todos os funcionários públicos estão submetidos ao RPPS: empregados em empresas públicas, agentes políticos, servidores temporários e detentores de cargos de confiança devem estar filiados ao Regime Geral de Previdência Social (RGPS). A alíquota de contribuição dos segurados ativos e inativos ao RPPS não poderá ser inferior à alíquota dos servidores titulares de cargo efetivo da União, atualmente fixada em 11\%, mas a base de incidência varia de acordo com a data de ingresso no serviço público. Os recursos previdenciários vinculados ao RPPS são aplicados conforme diretrizes previstas em norma específica do Conselho Monetário Nacional. No que se refere às fontes de receita 
da seguridade social (Saúde, Previdência Social e Assistência Social), estas advêm, em grande parte, das contribuições sociais constituída com a contribuição das empresas, dos empregadores domésticos, dos trabalhadores e de concursos prognósticos.

No tocante à educação, o artigo 212 da $\mathrm{CF} / 88$ prevê como fonte de financiamento para MDE os recursos oriundos de impostos e transferências (BRASIL, 1988). Aplicações financeiras, juros e multas dos impostos, Dívida Ativa de Impostos (DAI) e seus juros e multas também compõem receitas da MDE. A CF/ 88 prevê como fonte adicional o Salário-Educação (que não poder ser gasto com pagamento de pessoal), que é oriundo de uma contribuição social recolhida pelas empresas. A educação pode receber recursos adicionais dos royalties e participação especial, de serviços educacionais, convênios nacionais e internacionais, de programas, e de outras fontes de recursos.

Conforme visto, as receitas da seguridade social e da MDE ou mesmo da educação vêm de fontes bem distintas. Além disso, as despesas com previdência vêm de contribuições específicas para a formação de uma fonte de receitas próprias para essa despesa para a qual o trabalhador e o governo contribuem (RPPS), além de outras fontes de contribuições que financiam a seguridade social. Por outro lado, os recursos da MDE, que movimenta a maior parte dos recursos da educação, advêm integralmente de impostos e servem para manter e desenvolver o ensino.

Um dos principais argumentos dos governantes contrários à determinação constitucional de percentual mínimo de impostos para MDE é acerca do engessamento no orçamento, e é importante ressaltar que cabe exclusivamente ao Poder Executivo a elaboração das leis orçamentárias que devem ser aprovadas pelo Poder Legislativo. Com relação à União, as regras foram alteradas por força da EC n. 95/2016. Já os estados (que não alteraram as regras como fez a União) e o DF devem reservar 37\% (25\% MDE + 12\% Saúde) dos impostos, isso quando sua constituição não determinar um percentual acima do previsto na $\mathrm{CF} / 88$, para financiar as áreas sociais mencionadas; e os municípios 40\% (25\% MDE + 15\% Saúde) ou mais quando sua LOM determinar percentual mínimo acima do mínimo da $\mathrm{CF} / 88$.

No processo constituinte da sua Lei maior, em alguns estados e municípios, o percentual foi aumentado. Essa possibilidade ocorreu porque a $\mathrm{CF} / 88$ criou um piso e não um teto em relação ao percentual mínimo. Esse foi o argumento, na década de 1990, do ex-ministro do Supremo Tribunal Federal (STF), Sydney Sanches, ao analisar a Ação Direta de Inconstitucionalidade (ADI) 282, que questionava os dispositivos da Constituição do Mato Grosso, em relação ao percentual acima do previsto na $\mathrm{CF} / 88$. O ex-ministro decidiu que não haveria 
inconstitucionalidade nas Constituições Estaduais quando o percentual mínimo fosse acima do previsto na $\mathrm{CF} / 1988$. O plenário do Tribunal indeferiu o pedido de liminar para suspender os efeitos do dispositivo da Constituição que previa o percentual mínimo maior que o da CF/88 (BRASIL, 1990).

Contrariando o entendimento da ADI supracitada, em 1992, o plenário decidiu pela suspensão cautelar do dispositivo que determinava o percentual de 35\%, no mínimo, na MDE da Constituição do Estado do Rio de Janeiro. Em 2014, a ministra Carmem Lúcia, relatora da ADI 4102/RJ, que questionava o percentual na Constituição Fluminense, decidiu que o percentual acima do previsto na CF/88 limitava a autonomia do Poder Executivo acerca das leis orçamentarias e, portanto, era inconstitucional. O plenário acompanhou o entendimento da relatora. Os ministros Luís Roberto Barroso e Marco Aurélio participaram das duas votações e, na segunda, mudaram o voto acompanhando o parecer da relatora pela inconstitucionalidade (BRASIL, 2014).

Muitos entes federados descumprem os percentuais mínimos com a conivência dos Tribunais de Contas e das Casas Legislativas, como evidenciado por diversas pesquisas (VELLOSO, 1990; PINTO, 2005; MENEZES, 2008; SENA, 2009; DAVIES, 2012; BASSI; VERÇOSA, 2017; SOUZA, 2018). Governantes buscam, por meio de mudanças em sua Lei Maior, reduzir o percentual mínimo como, por exemplo, o estado de Goiás que alterou o percentual mínimo para MDE na sua Constituição Estadual, passando de 30\% para $28 \%$ e, atualmente, tenta, por meio da PEC 990, reduzir para 25\%. Contudo, como a diminuição de recursos é uma medida impopular, recorre-se ao seu simples descumprimento ou à judicialização para que não sejam obrigados a aplicar os "pisos" nas áreas sociais, como os exemplos dos estados mencionados anteriormente.

No Estado do Acre, houve aumento do percentual mínimo, contudo a estratégia de adotar uma medida popular de aumento de impostos na MDE estadual escondia a intenção do governo de inflar o novo percentual com despesas alheias à MDE. Como concluíram BASSI; VERÇOSA (2017, p. 315): “(...) sob um percentual superior ao piso estabelecido pela CF88, incluem-se e protegemse, sob o manto da vinculação, despesas forçosa e impropriamente identificadas como educacionais". Para o pesquisador Paulo Sena (2009, p. 17), essas novas categorias de despesas legais que inflam o percentual mínimo são "desvinculações brancas", pois se admite que o governo aplique parte do percentual mínimo em outras despesas que não se caracterizam como MDE. 


\section{AS INTERPRETAÇÕES ACERCA DAS DESPESAS COM OS INATIVOS DA EDUCAÇÃO}

A discussão acerca das despesas com inativos não é nova e tão pouco consensual na história do financiamento da educação brasileira. Intensifica-se, na década de 1980, com a regulamentação da EC 24/1983 (Emenda Calmon), especificamente, com a Lei federal 7.348/1985 (Lei Calmon), que regulamentou a emenda. Após a emenda ser promulgada, o Poder Executivo apresentou ao Congresso um Projeto de Lei (4.504/1984) que considerava, no seu art. 6, alínea $\mathrm{h}$, as despesas com inativos como despesas em MDE. Essa despesa se manteve no rol das permitidas com recursos da MDE no texto final da lei (BRASIL, 1984).

O debate pós-CF/88, sobretudo acerca da nova $\mathrm{LDB}$, também aborda a questão dos inativos. O substitutivo Sabóia (Parecer 250/1994-CE) retirava os gastos com inativos do conceito de MDE (art. 87, IX). Contudo, a despesa com inativos, na nova $\mathrm{LDB}$, não classificou essa categoria no rol permitido nem no proibido (artigos 70 e 71). Essa omissão tem sido um dos principais argumentos para a inclusão dessa despesa com recursos da MDE ou da educação.

Em 1997, o Conselho Nacional de Educação (CNE) se posicionou acerca do tema por meio do Parecer 26 do Conselho Pleno. Baseado no conceito do termo manutenção do ensino, como atividades que sustentam o funcionamento regular, e de desenvolvimento, como atividades que democratizam ou expandem a oferta e aprimoram a qualidade do ensino, o Conselho apreendeu que os inativos não contribuem nem para a manutenção nem para o desenvolvimento do ensino (BRASIL, 1997). Embora tivesse expressado que a LDB é omissa em relação ao tema, compreendeu que, devido ao seu espírito, essa despesa não é aceitável.

Com a tramitação no Congresso dos projetos acerca do Plano Nacional de Educação (PNE), em 1998, o tema dos inativos voltou à tona. O Projeto de Lei 4.155, apresentado pelo deputado Ivan Valente, previa como meta para o financiamento da educação: "Garantir os recursos do Tesouro Nacional para o pagamento de aposentados (com paridade de remuneração) e pensionistas não como verbas de manutenção e desenvolvimento da educação" (BRASIL, 1998). Contudo, na Lei federal 10.172/2001, não houve a manifestação acerca desse tema.

Com a discussão no Congresso Nacional da Medida Provisória 339, de 2006, que regulamentava o Fundo de Manutenção e Desenvolvimento da Educação Básica e de Valorização dos Profissionais da Educação (Fundeb), o debate foi reacendido. Alguns docentes inativos de São Paulo solicitaram, no Congresso, o reexame da proibição do pagamento dos inativos com recursos do Fundo, conforme proposto pelas emendas 121 e 122, de autoria, respectivamente, 
dos deputados Carlos Abicalil e Gastão Vieira. Os aposentados alegaram os seguintes motivos para serem pagos com recursos do Fundeb: o inativo recebe aposentadoria pelo que ele fez quando em atividade, não pelo que ele faz depois de aposentado; retirar os aposentados das despesas com MDE faria com que essa despesa aumentasse em igual proporção para atender aos percentuais previstos no artigo 212; deixar de pagar os inativos com recursos da MDE, os tornaria um peso inútil, uma vez que nem mesmo poderiam fazer greve para reivindicar tais direitos; alegaram que se a despesa com inativos ficasse de fora do percentual mínimo poderia sofrer redução de recursos, o que afetaria o pagamento dos proventos, que segundo eles são extensões da remuneração. Por esses motivos, eles afirmaram que deveriam estar incluídos no rol de despesas do Fundeb. As emendas não foram aprovadas, e a lei do Fundeb foi omissa, especificamente, sobre esse assunto (BRASIL, 2007c).

O Ministério da Educação (MEC) entende que, embora a LDB tenha sido omissa em relação ao pagamento de inativos com recursos da MDE, essa despesa não pode ser realizada com esses recursos, conforme o documento "Perguntas Frequentes" do Fundo Nacional de Desenvolvimento da Educação (FNDE), o qual mostra que, na maioria dos entes subnacionais que incluem essa despesa na MDE, os Tribunais de Contas entendem que ela deve ser eliminada com planejamento e regulação (BRASIL, 2008).

Um equívoco do Ministério é considerar que a maioria dos Tribunais de Contas proíbe tal gasto, uma vez que a pesquisa que embasa o artigo tem apresentado vários entendimentos a favor dessa prática, inclusive com regulamentação dos próprios Tribunais. Além disso, a competência para legislar sobre o assunto é da União e até o presente momento isso não aconteceu, o que demonstra que a proibição do MEC/FNDE é inócua, sendo o órgão conivente com tal prática. A Controladoria-Geral da União (CGU), apresentou argumentos técnicos quanto à ilegalidade do pagamento de inativos provenientes da educação, referenciando o art. 70 da LDB e a Lei do Fundeb na cartilha Olho Vivo no Dinheiro Público - FUNDEB (BRASIL, 2012).

Com a aprovação da Lei de Responsabilidade Fiscal (LRF) - Lei Complementar 101/2000 -, a STN iniciou-se a publicação do Manual de Demonstrativos Fiscais a fim de orientar os entes federados em relação aos padrões de regras contábeis e orçamentárias. Em relação ao pagamento de inativos com recursos da educação, a STN foi omissa até a publicação do Manual 7, em 2007, quando se posicionou contra essa despesa contabilizada na MDE (BRASIL, 2007b). 
Segundo o atual Manual, do exercício de 2019, a orientação é pela não contabilização, pois o artigo 70, inciso $\mathrm{I}$, da LDB, prevê como despesas a remuneração e o aperfeiçoamento do pessoal docente e demais profissionais da educação, excetuando-se as despesas com pessoal quando em desvio de função ou em atividade alheia à MDE (BRASIL, 2018d).

Remetendo à $\mathrm{CF} / 88$, artigos 37 e 40, o Manual demonstra que o termo remuneração se refere aos servidores ativos, provento para os inativos e pensão para os pensionistas. Nesse sentido, pagar proventos e pensões com recursos da MDE é um equívoco. O Manual cita, ainda, o artigo 22, inciso I, da lei do Fundeb, que define a destinação dos recursos do Fundo para o pagamento da remuneração dos profissionais do magistério da educação básica em efetivo exercício na rede pública. O Manual orienta que as despesas com inativos e pensionistas devem ser mais apropriadamente classificadas como Previdência. Para o pesquisador Nicholas Davies (2011, p. 120), a CF/88 “considera o pagamento dos inativos como proventos, e não como remuneração, e que o conceito de MDE é restrito à remuneração - para quem está na ativa -, e não a proventos".

A discussão chegou até o STF através de quatro ADIs propostas pela Procuradoria-Geral da República contra normas estaduais que tentam permitir essas despesas na educação. Em 2016, o ex-procurador-geral da República, Rodrigo Janot, ajuizou no STF a ADI 5546, contra os incisos I e V do artigo $2^{\circ}$ da Lei estadual 6.676/1998, da Paraíba, que inclui, nas despesas com MDE, os proventos e encargos de professores inativos. O ex-procurador alegou que editar normas gerais da educação é competência legislativa privativa da União e que a LDB não prevê as despesas com inativos como MDE. Além disso, alegou que o pagamento de inativos é de responsabilidade previdenciária do ente da federação (BRASIL, 2016b).

A ADI 5719, de 2017, foi impetrada também pelo ex-procurador Rodrigo Janot com pedido de liminar contra dispositivos da Lei Complementar 1.010/2007, que dispõe sobre a criação da São Paulo Previdência (SPPREV), entidade gestora do RPPS e do Regime Próprio de Previdência dos Militares do Estado de São Paulo (RPPM) estadual. Segundo a ADI, as normas questionadas permitem ao estado de São Paulo contabilizar despesas com inativos e pensionistas ou com a cobertura de déficit de regime próprio de previdência na MDE. O ex-procurador alegou que a Lei federal 7.348/1985, que previa a despesa com inativos entre as possíveis com MDE, foi revogada tacitamente pela $\mathrm{LDB}$, que, por sua vez, define no artigo 70 as despesas possíveis com MDE e não prevê as com inativos (BRASIL 2017a). 
Coaduna com o que defende o ex-procurador, o pesquisador Jorge Abrahão de Castro (2008, p. 15-16): "foi a intenção do legislador afirmar que mesmo sendo as despesas aceitas, só seriam admitidas se fossem realizadas com vistas aos objetivos básicos das instituições educacionais - daí o foco dirigir-se para a escola e para o aluno". O procurador alegou, ainda, que normas próprias de lei geral são de competência legislativa da União, que viola a destinação constitucional específica do artigo 212 e transgride a cláusula de não vinculação de impostos do artigo $167 \mathrm{da}$ CF/88.

Já a ADI 5691 foi impetrada, em 2017, pela procuradora-geral da República, Raquel Dodge, contra uma resolução do Tribunal de Contas do Espírito Santo (238/2012), que inclui os encargos relativos aos inativos da educação (inclusive déficit do regime próprio de previdência) nas despesas com MDE. A procuradora alegou usurpação de competência privativa da União para dispor sobre diretrizes e bases da educação nacional e que as despesas com contribuições destinadas a cobrir déficit de RPPS não poderiam ser consideradas como de MDE (BRASIL, 2017b).

A mais recente ADI 6049 foi impetrada, em 2018, pela procuradora Raquel Dodge, contra a Lei Complementar 147/2018 do Estado de Goiás, com o objetivo de alterar a Lei Complementar 28/1998 (que estabelece as diretrizes e bases do Sistema Educativo do Estado de Goiás) para incluir o pagamento de pessoal inativo nas despesas com MDE. A procuradora pediu a medida liminar para suspender os efeitos da lei complementar estadual e a futura declaração de inconstitucionalidade. O governo justifica a inclusão da despesa, entre outros motivos, afirmando que há outros entes federados que incluem tal despesa na educação e que a Lei federal 7.348/85 permite essa despesa na MDE (BRASIL, 2018a).

A decisão monocrática do ministro-relator Ricardo Lewandowski foi contrária à possibilidade de essa despesa ser custeada com recursos da MDE. O ministro-relator acatou os argumentos apresentados na petição inicial da procuradora, que sustentou que aos entes subnacionais não compete legislar sobre despesas na MDE. Alegou também que é indevida a vinculação de receita da MDE para despesa previdenciária e que o percentual mínimo se torna fictício ao ser inflado por despesas alheias à MDE. Além disso, defendeu que as despesas com inativos prejudicam diariamente a educação por reduzir os recursos públicos destinados à sua melhoria.

Em sua decisão, o ministro-relator fez uma oportuna distinção entre remuneração e provento, afirmando que este último não está previsto no artigo 70 da LDB, que trata das despesas possíveis em MDE. A Procuradoria-Geral do Estado de Goiás afirmou que irá recorrer da decisão. A ADI deverá ser apreciada, 
ainda, pelo plenário do STF para que se tenha um acórdão em relação a esse tema. Contudo, a decisão monocrática pode ser vista como um avanço, sobretudo, porque as demais ADIs sequer receberam uma decisão de seus relatores.

O Tribunal de Contas da União (TCU) também se manifestou acerca do tema, por meio do Acórdão 1656, de 2019, reconhecendo que tal despesa é objeto de controvérsia quanto ao seu enquadramento como MDE (BRASIL, 2019b). Afirma que alguns estados têm um percentual mínimo para aplicar em MDE acima do percentual da CF/88 e que isso tem ensejado a ampliação do conceito de MDE para que o alcance do percentual determinado em sua Lei Maior seja cumprido e o fazem com a conivência dos Tribunais de Contas. Há uma inconsistência nessa afirmação, pois, conforme constata esta pesquisa, mesmo os estados que devem aplicar somente 25\% têm incluído as despesas de inativos na MDE (ver Tabela I, mais adiante). Aliás, o próprio colegiado do STF, em 2014, decidiu que os estados não precisam cumprir os percentuais mínimos determinados em suas Constituições, quando acima do percentual mínimo da $\mathrm{CF} / 88$.

O TCU afirma que, devido ao aumento das despesas com inativos, o cumprimento do percentual mínimo pelos entes subnacionais fica comprometido, o que se pode constatar neste artigo, pois, se retirado o montante de recursos nessas despesas, a maioria não alcança o percentual mínimo de $25 \%$. O acórdão descreve os argumentos do FNDE/MEC, do CNE e das ADIs em andamento no STF, no que se refere à defesa dos equívocos jurídico e material de se compreender despesas de inativos como de MDE. O TCU apresenta a argumentação de que os inativos contribuíram com parcela de seus rendimentos para o regime previdenciário e essas contribuições foram consideradas como gastos em MDE.

Ao considerar o pagamento dos proventos e pensões como despesa da MDE, ocorre uma dupla contabilização com inativos, o que fere dispositivos da $\mathrm{CF} / 88$. Conforme o Anuário Estatístico da Previdência Social (AEPS), a maioria dos entes federados possuem déficits previdenciários, mas, se considerarmos que a maioria dos estados paga parte da previdência com recursos da educação, pode haver uma dupla contabilização, pois os inativos dessa área correspondem a uma parte significativa dos inativos em geral. Se os recursos para pagá-los não estão saindo da previdência, não é razoável acreditar que haja déficit em muitos desses estados. A menos que a despesa esteja sendo contabilizada duas vezes (na educação e na previdência). Se assim for, a pergunta que deve ser feita é onde está sendo alocado esse recurso que é contabilizado duplamente? Essa é uma tarefa, sobretudo, para os órgão judiciais que devem zelar pelo cumprimento das leis. 


\section{OS TRIBUNAIS DE CONTAS E AS SUAS CONTROVERTIDAS INTERPRETAÇÕES}

Os Tribunais de Contas exercem uma função primordial no processo de fiscalização dos recursos da educação. São órgãos que auxiliam o Poder Legislativo na elaboração técnica dos pareceres das contas dos governos que, pelo menos legalmente, embasam o voto dos parlamentares às contas do Executivo em cada exercício financeiro. Portanto, é preciso compreender que os Tribunais são compostos pela equipe técnica, que analisa com certo critério as contas, e o conselheiro-relator, que emite o parecer prévio nas contas, que é votado em sessão plenária pela Corte. A maioria de seus conselheiros é escolhida pelo chefe do Poder Executivo e pelo Legislativo, o que ajuda a explicar o motivo pelo qual, em muitos casos, a equipe técnica aponta diversas ilegalidades e desvios nas contas, e o parecer do relator quase sempre é favorável à aprovação das contas. Outro fato importante é que muitas normas criadas pelos Tribunais para regulamentar a prestação de contas dos governos contêm equívocos quanto ao que definem como receita e despesa em MDE conforme constatado na pesquisa de Nicholas Davies sobre os procedimentos de verificação dos recursos da educação pelos Tribunais de Contas (DAVIES, 2003). Além disso, não é incomum que os governos não cumpram o determinado pela norma. Aliás, há casos em que o próprio Tribunal não cumpre, como veremos adiante neste artigo. Essa fragilidade denota que há interesses que vão além da aplicação devida e da fiscalização sistemática dos recursos públicos no âmbito desses órgãos.

Com relação às normas e às decisões dos TCE, é possível encontrar as mais variadas interpretações acerca da despesa com inativos. Para exemplificar, utilizaremos o caso do TCE-MG. As Instruções Normativas (IN) 02/1991, 02/1997 e 01/1999 permitiam os gastos de inativos por meio da manobra de incluí-los, indevidamente, no rol de despesas em MDE, tendo como sustentação a Lei federal 7348/1985. Essas INs incluíram um inciso no rol de despesas da MDE, contrariando a LDB. Segundo esse inciso, seriam consideradas despesas com MDE as que decorressem da manutenção de pessoal inativo, estatuário, originário das instituições de ensino, em razão de aposentadoria (MINAS GERAIS, 1991, 1997, 1999).

As INs 02/2002, 08/2004, 03/2007, 06/2007, 13/2008, apesar de, contraditoriamente, excluírem o inciso previsto nas INs, citadas anteriormente, e proibirem até mesmo o pagamento da contribuição previdenciária patronal (o que contraria a lei), previam em seus anexos, que orientam os governos no preenchimento das receitas e despesas em MDE, a despesa com previdência. A IN 01/2010, que modificou a IN 13/2008, excluiu os inativos e a contribuição 
patronal do cômputo da educação. Com essa nova alteração, ficaram expressamente proibidos, na composição do índice de aplicação no ensino, os gastos com inativos da educação. Porém, a instrução afirma que o TCE-MG poderá estabelecer prazo para o Executivo se adequar à nova norma, o que demonstra que a medida não seria tomada imediatamente após o vigor da IN. As IN 9/11, IN 12/11 e IN $5 / 12$ mantiveram a interpretação de que a despesa com inativos não deve ser computada na educação e a excluía em seus anexos (MINAS GERAIS, 2002, 2004, 2007a, 2007b, 2008, 2010, 2011a, 2011b, 2012).

Em 2011, foi realizada uma consulta solicitada pelo presidente da Associação Mineira de Municípios (AMM) ao TCE-MG acerca da possibilidade de aplicação dos recursos da educação para pagamento dos inativos, uma vez que o sistema informatizado do TCE-MG e a IN 13/2008 previam a contabilização, mas a despesa não estaria prevista no sistema do MEC. Isso estaria impedindo a habilitação dos municípios mineiros para o recebimento automático dos recursos da União. A maioria dos conselheiros do Tribunal entendeu que a despesa com inativos não pode ser computada na educação. Contudo permitiram que ela fosse contabilizada até que a previdência do estado e dos municípios fosse capitalizada pelo Tesouro para suportar os gastos que deixariam de ser da educação e passariam para previdência. Além disso, argumentaram que, se os municípios do Estado tivessem que alocar novos recursos na educação, haveria uma desfiguração total do orçamento porque não haveria disponibilidade para isso (MINAS GERAIS, 2011c).

É notório, pelo que foi esclarecido pelos conselheiros do TCE-MG, que os governos poderiam aplicar recursos da educação para pagamento de inativos. Pela análise do Parecer Prévio das Contas emitido pelo TCE-MG, do Parecer Prévio das Contas do Governo, emitido pelo Ministério Público de Contas e das Leis Orçamentárias, de 2019, aparentemente, o governo mineiro não tem utilizado recursos da educação para o pagamento de inativos, mas não se pode afastar a hipótese de que essa despesa esteja elíptica em outra despesa mais genérica.

Há casos em que o Poder Executivo regulamentou, por meio de lei ou até mesmo de mudança de sua Lei Maior, através de emenda, conforme fez o estado de Goiás, a possibilidade de incluir os inativos nas despesas com educação. Como foi observado anteriormente, alguns desses governos estão sendo questionados quanto à constitucionalidade dessas normas no âmbito do STF. O Quadro I, a seguir, apresenta as normas regulamentadoras dos Tribunais (estaduais, distrital, municipais e da União) que versam sobre as receitas e despesas da MDE ou da educação, especificamente acerca de inativos, o posicionamento da equipe técnica dos Tribunais e o parecer do plenário do TCs acerca das contas. 


\section{Quadro I - Posicionamento dos Tribunais de Contas acerca do pagamento de inativos da educação}

\begin{tabular}{|c|c|c|c|c|}
\hline UF & NORMA & DETERMINAÇÃO & $\begin{array}{c}\text { EQUIPE } \\
\text { TÉCNICA TC }\end{array}$ & PLENÁRIO \\
\hline TCE-AC & Não foi encontrada norma. & - & Aceita* & Favorável \\
\hline TCE-AL & Não foi encontrada norma. & - & Aceita & Favorável \\
\hline TCE-AP & $\begin{array}{l}\text { Resolução Normativa n. 161, de } \\
2014 .\end{array}$ & Proíbe despesa com inativos. & Aceita** & Favorável \\
\hline TCE-AM & Não foi encontrada norma. & - & Aceita & Favorável \\
\hline TCE-BA & Resolução n. 000082, de 2017. & Proíbe despesa com inativos. & Não aceita & Favorável \\
\hline TCM-BA & Resolução n. 000082, de 2017. & Proíbe despesa com inativos. & Não aceita & - \\
\hline TCE-CE & $\begin{array}{l}\text { Instrução Normativa n. 001, de } \\
2019 .\end{array}$ & Proíbe despesa com inativos. & Não aceita & Favorável \\
\hline TC-DF & Decisão n. 2495/2003 e 8187/2008 & Proibe despesa com inativos. & Não Aceita*** & Favorável \\
\hline TCE-ES & Resolução n. 238, de 2012. & Permite despesa com inativos. & Não aceita & Favorável \\
\hline TCE-GO & $\begin{array}{l}\text { Resolução Normativa n. 001, de } \\
\qquad 2001 .\end{array}$ & Proíbe despesa com inativos. & Não aceita & Favorável \\
\hline TCM-GO & $\begin{array}{l}\text { Resolução Normativa n. 007, de } \\
\qquad 2008 .\end{array}$ & Proíbe despesa com inativos. & Não aceita & - \\
\hline TCE-MA & Instrução Normativa n. 14, de 2007. & Proíbe despesa com inativos. & Aceita & Favorável \\
\hline TCE-MT & Não foi encontrada norma. & - & Aceita & Favorável \\
\hline TCE-MS & Não foi encontrada norma. & - & Aceita & Favorável \\
\hline TCE-MG & Instrução Normativa n. 05, de 2012. & Proíbe despesa com inativos. & Não aceita & Favorável \\
\hline TCE-PA & Não foi encontrada norma. & - & - & Favorável \\
\hline TCM-PA & Instrução Normativa n. 01, de 1996. & Permite despesa com inativos. & Aceita & - \\
\hline TCE-PB & $\begin{array}{c}\text { Acórdão - TC 583, de 2008/TC } \\
4533 / 16\end{array}$ & Proíbe despesa com inativos. & Não aceita & Favorável \\
\hline TCE-PR & Não foi encontrada norma. & - & - & Favorável \\
\hline TCE-PE & Resolução n. 0005, de 2001. & Proíbe despesa com inativos. & Aceita & Favorável \\
\hline TCE-PI & Resolução n. 1.194, de 2002. & Permite despesa com inativos. & Aceita & Favorável \\
\hline TCE-RR & $\begin{array}{l}\text { Instrução Normativa n. 002, de } \\
2014 .\end{array}$ & Proíbe despesa com inativos. & Não aceita & Favorável \\
\hline TCE-RO & Instrução Normativa n. 22, de 2007. & Não faz referência & Não aceita & Favorável \\
\hline TCE-RJ & Não foi encontrada norma. & - & Aceita**** & Desfavorável \\
\hline TCM-RJ & Não foi encontrada norma. & - & Aceita & Favorável \\
\hline TCE-RN & Resolução n. 012, de 2016. & Não faz referência. & Aceita & Favorável \\
\hline TCE-RS & Não foi encontrada norma. & - & Aceita & Favorável \\
\hline TCE-SC & Não foi encontrada norma. & - & Não aceita & Favorável \\
\hline TCE-SP & Não foi encontrada norma. & - & Aceita & Favorável \\
\hline
\end{tabular}




\begin{tabular}{|c|c|c|c|c|}
\hline UF & NORMA & DETERMINAÇÃo & $\begin{array}{c}\text { EQUIPE } \\
\text { TÉCNICA TC }\end{array}$ & PLENÁRIO \\
\hline TCM-SP & Não foi encontrada norma. & - & Aceita ${ }^{* * * *}$ & Favorável \\
\hline TCE-SE & Resolução n. 243, de 2007. & Proíbe despesa com inativos. & Não aceita & Favorável \\
\hline TCE-TO & Instrução Normativa n. 6, de 2013. & Proíbe despesa com inativos. & Não aceita & Favorável \\
\hline TCU & TC-020.079/2018-4. & Proíbe despesa com inativos. & Aceita & Favorável \\
\hline
\end{tabular}

* Prestação de Contas 2015.

** Desde 2006 o TCE-AP não emite parecer nas contas do governo.

***Aceita o pagamento de inativos da educação com recursos do FCDF.

****Aceita, mas decidiram pela exclusão a partir do exercício financeiro de 2020 .

*****A lei determina que teria que excluir, totalmente, em 2018, mas não foi cumprida. (Lei municipal 15.963/2014).

Fonte: Sites dos Tribunais de Contas. Quadro elaborado pelo autor.

Nem todos os Tribunais têm normas que tratam especificamente do assunto, além disso a pesquisa foi realizada através do site dos Tribunais, em agosto de 2019, e alguns não têm a prática de publicizá-las. Como se pode constatar, a maior parte dos Tribunais editou normas que regulamentam a matéria, e a maioria delas proíbe as despesas com inativos na educação. Os Tribunais (TCEES, TCM-PA e TCE-PI) permitem em suas normas a aplicação de recursos da educação com inativos. Em 13 Tribunais não foi possível encontrar, no site, norma que regulamente o assunto; pode-se inferir que a maioria deles não tem norma, conforme se constatou na análise do relatório do parecer do Tribunal nas contas desses governos.

Com relação ao parecer dos Tribunais, foi considerado o último em que este está disponível no site. $\mathrm{O}$ dado relevante é que, embora a maioria tenha norma que não permite a despesa, a maioria das equipes técnicas, dos(as) conselheiros(as) relatores(as) e do plenário do Tribunal aceita a despesa com inativos. Nos Relatórios das Contas dos TCE-PA e TCE-PR, não foi possível constatar se aceitam ou não as despesas, pois não houve posicionamento e/ou detalhamentos das despesas em MDE ou mesmo da educação. A falta de detalhamento foi alvo de críticas pelo MPC-AL no seu parecer nas contas do governo de 2011. Embora reconhecesse a prática do governo de incluir inativos não foi possível saber o valor e, portanto, se este fosse excluído afetaria o cumprimento do limite constitucional em MDE (ALAGOAS, 2011). Apenas o TCE-RJ emitiu parecer desfavorável às contas do governador, em 2018, contudo, a ALERJ aprovou-as (RIO DE JANEIRO [Estado], 2018).

O governo municipal do Rio de Janeiro, além de contabilizar gastos com inativos na MDE, em 2011, sob os auspícios do Banco Interamericano de Desenvolvimento (Bird) e de olho nos R $\$ 1,45$ bilhão em empréstimos, concedidos para implementar as mudanças na previdência proposta pelo banco, sancionou a 
Lei municipal 5.300/2011, que dispõe sobre o Plano de Capitalização do Fundo Especial de Previdência do Município do Rio de Janeiro (Funprevi) cujo objetivo, entre outras coisas, é determinar a contribuição suplementar relativa à educação e à saúde como despesas dessas áreas (RIO DE JANEIRO [Cidade], 2011).

Em 2018, a Coordenadoria de Auditoria e Desenvolvimento (CAD), órgão técnico do TCM-RJ, apurou que mais de R $\$ 42$ milhões da MDE foram aplicados indevidamente na formação da contribuição ao Funprevi, que recebeu mais de R \$ 1,2 bilhão dos recursos da MDE (RIO DE JANEIRO [Cidade], 2018). Cabe ressaltar que a CAD sempre se manifestou contra os gastos com inativos na MDE, mas o Tribunal tem aceitado tal despesa.

Os Tribunais de Goiás, Pernambuco, Rio de Janeiro, Santa Catarina e o do município de São Paulo mesmo entendendo que a despesa não deve ser paga pelos recursos da educação, adotaram sua exclusão progressiva por meio da determinação da criação de Plano de Exclusão, tendo como justificativa o impacto da exclusão total em apenas um exercício financeiro (GOIÁS, 2008; PERNAMBUCO, 2001; RIO DE JANEIRO [Estado], 2018; SÃO PAULO [Cidade], 2001; 2014). Uma medida controversa, pois, mesmo entendendo que a despesa não mantém nem desenvolve o ensino, os Tribunais concordaram em aceitar a despesa por vários exercícios financeiros até a sua possível exclusão total. Contudo, no caso de Goiás, em 2008, por determinação do TCE-GO, o governo implementou um Plano de Exclusão de 10\% ao ano até a extinção de 100\% dessa despesa. Na prática, apenas em 2011, o governo iniciou a exclusão, porém os valores com inativos aumentaram vertiginosamente a partir de 2009, sobretudo com proventos e pensões acima de $\mathrm{R} \$ 10.000,00$. Além disso, o governo incluiu o pagamento de inativos de áreas alheias à educação. Contraditoriamente, em 2017, o TCE-GO aceitou a inclusão dos gastos com inativos na educação, contrariando a sua própria decisão de não aceitar tal gasto (SOUZA, 2018).

No caso do TCE-PE, a Resolução 14, de 2001, determinou a exclusão dos gastos com inativos (PERNAMBUCO, 2001). No entanto, o governo não cumpriu a determinação de Tribunal e continuou contabilizando a contribuição complementar da Secretaria de Educação ao fundo de aposentadorias e pensões, contabilizando a diferença entre os valores pagos aos inativos e pensionistas, oriundos da Secretaria de Educação e a arrecadação previdenciária dos servidores desta.

O TCE-RJ passou a considerar indevidos os gastos com inativos a partir do afastamento da maioria dos conselheiros envolvidos em casos de corrupção, denunciados na operação da Polícia Federal denominada de "Quinto do Ouro". A determinação do Tribunal é que, a partir de 2020, o governo estadual e os municipais não contabilizem mais a despesa de inativos na MDE. Porém a 
determinação poderá não ser cumprida, pois ainda não há clareza legal acerca da possibilidade ou não de pagamento aos inativos com recursos da educação, o que poderá conduzir os governantes a recorrerem da decisão do TCE-RJ (RIO DE JANEIRO [Estado], 2018).

Em 2007, um ano após a recomendação do TCE-SC de excluir as despesas com inativos da MDE, a Secretaria da Fazenda apresentou um Plano de Exclusão prevendo uma redução dos gastos com inativos na educação em um período de 20 exercícios financeiros, sendo o percentual de exclusão $5 \%$ do valor total da despesa. O Plano não foi aceito pelo Tribunal, que justificou que a despesa, segundo a LDB e a STN, não deve ser aceita (SANTA CATARINA, 2007). Controversamente, o governo sempre incluiu a despesa na MDE, cujo resultado foi a não aplicação de mais de R \$ 5,5 bilhões na MDE, de 2009 a 2017, e sempre recebendo parecer prévio favorável pelos Conselheiros-Relatores do Tribunal e o parecer favorável do plenário do Tribunal (SANTA CATARINA, 2017).

No Município de São Paulo, as despesas com inativos eram aceitas pelo TCM por força da Lei municipal 13.245, de 2001, que permitia essa despesa como típica da MDE. Em 2014, a lei supramencionada foi alterada pela Lei 15.963, que determinou a exclusão gradativa dos gastos com inativos da MDE, tendo a sua exclusão total em 2018. Contudo, espertamente, a nova legislação incluiu os gastos com inativos, excluídos da MDE, na educação. Sendo assim, a despesa com inativos continua na educação, mas não no percentual mínimo (SÃO PAULO [Cidade], 2001, 2018).

O Poder Legislativo exerce uma função essencial na fiscalização das contas do governo, uma vez que é o responsável por aprová-las ou não. Diante disso, tem a responsabilidade de investigar o Poder Executivo através da instauração de Comissão Parlamentar de Inquérito (CPI). Não há muitos registros de CPIs que tenham investigado a aplicação dos recursos da educação, enfatizando os gastos com inativos. Na Assembleia Legislativa do Estado de São Paulo (Alesp), em 1999, foi instaurada uma CPI para apurar o não cumprimento da destinação mínima obrigatória de impostos para MDE pelo governo estadual. Os parlamentares membros da CPI consideraram as despesas com inativos indevidas. O Conselho Estadual de Educação (CEE) de São Paulo editou normas proibindo os gastos com inativos e determinando um Plano de Exclusão das despesas. Contudo, segundo a Secretaria de Fazenda o Conselho Estadual não tem a prerrogativa de normatizar a matéria. Dentre outros resultados, a CPI apurou que houve o uso de recursos do Salário-Educação com pagamento dos inativos, o que contraria a lei (SÃO PAULO [Estado], 1999). 


\section{OS RECURSOS DA EDUCAÇÃO PARA O PAGAMENTO DOS INATIVOS}

É possível constatar manobras contábeis, no âmbito dos governos estaduais, que permitem que os governantes incluam na MDE ou mesmo na educação a despesa com inativos. Para chegar a essa conclusão, foi necessário analisar diversos documentos contábeis dos governos estaduais e da União para construir a Tabela I (segue abaixo) e demonstrar os valores aplicados em inativos ou com déficit previdenciário como fazem os governos estaduais do Espírito Santo e São Paulo (ESPÍRITO SANTO, 2018; SÃO PAULO [Estado], 2018). Os documentos com dados orçamentários ainda são um desafio tanto para serem encontrados, como para serem interpretados.

O documento principal utilizado foi o Relatório das Contas, emitido pela equipe do Tribunal de Contas dos governos estaduais e da União, porém nem todos os Tribunais os disponibilizam e muitos que disponibilizam não detalham as despesas com MDE e educação. Por isso se recorreu a outros documentos, como o Relatório das Contas do Ministério Público de Contas e/ou ao Relatório da Controladoria do governo. Esse último, por ser órgão da administração direta, não detalha as irregularidades e os desvios. No Relatório Resumido da Execução Orçamentária (RREO) foram encontrados os dados da Receita Líquida, do montante de recursos aplicados em MDE e do percentual equivalente, mesmo porque a Lei de Responsabilidade Fiscal 101/2000 determina a divulgação de tais dados através do RREO. Na Lei Orçamentária Anual (LOA), foram encontrados dados mais detalhados acerca da previsão de despesas na MDE e na educação, sobretudo com inativos, o que possibilitou a construção da tabela a seguir.

Evidentemente na LOA há um detalhamento maior acerca da previsão das receitas e das despesas, pois, caso isso não acontecesse, o governo estaria contrariando a CF/88, no seu artigo 169. Foi encaminhado um e-mail para todas as secretarias estaduais e para a distrital, solicitando informações acerca dos valores aplicados com inativos com recursos da MDE ou da educação. Contudo, transcorridos seis meses, apenas quatro governos estaduais responderam, mas sem nenhum dado específico. Alguns Tribunais de Contas e MPC realizaram análises detalhadas acerca do pagamento de inativos com recurso da MDE ou da educação como: São Paulo, Espírito Santo, Goiás e Rio de Janeiro (SÃO PAULO [Estado], 2018; ESPÍRITO SANTO, 2018; GOIÁS, 2008; RIO DE JANEIRO, 2018). No caso do TCE da Paraíba, os técnicos do Tribunal excluíram as despesas com inativos da MDE. 
A Tabela I, logo abaixo, apresenta na primeira coluna as siglas dos estados e do DF em ordem alfabética; a última linha se refere à União. A segunda coluna apresenta os exercícios financeiros analisados. Eles diferem, pois nem sempre os dados do mesmo exercício financeiro estavam disponíveis on-line para todos os entes. A terceira coluna apresenta os valores da Receita Líquida, que é a base para o cálculo do percentual mínimo. Na quarta, estão expostos os dados que os governos alegam ter aplicado em MDE, seguidos pela quinta coluna, que informa o percentual aplicado em MDE. Na sexta coluna constam os valores nominais, ou a previsão, das despesas com inativos, seguidos da coluna com o percentual calculado a partir da subtração das despesas com inativos da MDE. A última coluna traz a diferença entre o percentual informado pelos governos e o percentual calculado sem as despesas com inativos. Como a maioria dos dados acerca da despesas com inativos foi retirada da LOA, os valores se referem à despesa prevista, ou seja, passível de alteração pelo governo na execução. As fontes dos dados contidos na Tabela I estão no Anexo desta pesquisa.

\section{Tabela I - Dados sobre as receitas e despesas em MDE e despesas com inativos da educação - Valores nominais $(R \$ 1,00)$}

\begin{tabular}{|c|c|c|c|c|c|c|c|}
\hline UF & Exc. Fin & Receita Líquida & MDE & $\%$ MDE & $\begin{array}{l}\text { Despesas com } \\
\text { Inativos elou déficit } \\
\text { previdenciário }\end{array}$ & $\begin{array}{l}\% \text { da MDE } \\
\text { sem os } \\
\text { Inativos }\end{array}$ & $\begin{array}{c}\text { Diferença } \\
\text { dos } \%\end{array}$ \\
\hline$A C$ & 2016 & $\mathrm{R} \$ 4.067 .702 .443,49$ & $\mathrm{R} \$ 1.032 .413 .953,05$ & $25,38 \%$ & $\mathrm{R} \$ 171.315 .193,93$ & $21,17 \%$ & $4,21 \%$ \\
\hline $\mathrm{AL}$ & 2017 & $\mathrm{R} \$ 7.092 .314 .150,74$ & $\mathrm{R} \$ 1.821 .571 .981,41$ & $25,68 \%$ & $\mathrm{R} \$ 369.900 .495,00$ & $20,47 \%$ & $5,21 \%$ \\
\hline AP & 2017 & $\mathrm{R} \$ 3.679 .875 .484,00$ & $\mathrm{R} \$ 1.106 .593 .274,00$ & $30,07 \%$ & - & - & - \\
\hline AM & 2016 & $\mathrm{R} \$ 8.643 .650 .711,56$ & $\mathrm{R} \$ 2.171 .837 .537,06$ & $25,13 \%$ & $\mathrm{R} \$ 934.763 .000,00$ & $14,31 \%$ & $10,82 \%$ \\
\hline $\mathrm{BA}$ & 2016 & $\mathrm{R} \$ 43.307 .602 .209,09$ & $\mathrm{R} \$ 9.859 .116 .339,12$ & $22,77 \%$ & - & - & - \\
\hline CE & 2017 & $\mathrm{R} \$ 16.317 .702 .063,71$ & $\mathrm{R} \$ 4.480 .816 .560,67$ & $27,46 \%$ & - & - & - \\
\hline DF & 2017 & $\mathrm{R} \$ 15.790 .866 .000,00$ & $\mathrm{R} \$ 4.238 .099 .000,00$ & $27,41 \%$ & $\mathrm{R} \$ 1.084 .479,00$ & $26.83 \%$ & $0,48 \%$ \\
\hline ES & 2017 & $\mathrm{R} \$ 9.399 .404 .444,04$ & $\mathrm{R} \$ 2.603 .106 .048,25$ & $27,69 \%$ & $\mathrm{R} \$ 717.958 .661,60$ & $20,06 \%$ & $7,63 \%$ \\
\hline GO & 2017 & $\mathrm{R} \$ 16.061 .260 .187,00$ & $\mathrm{R} \$ 3.935 .558 .074,00$ & $24,50 \%$ & $\mathrm{R} \$ 1.535 .046 .209,00$ & $14,95 \%$ & $9,55 \%$ \\
\hline MA & 2016 & $\mathrm{R} \$ 11.672 .368 .289,00$ & $\mathrm{R} \$ 3.102 .841 .841,00$ & $26,59 \%$ & $R \$ 25.963 .385,52$ & $26,36 \%$ & $0,23 \%$ \\
\hline MT & 2017 & $\mathrm{R} \$ 9.459 .934 .962,19$ & $\mathrm{R} \$ 2.489 .019 .284,47$ & $26,31 \%$ & $\mathrm{R} \$ 423.337 .677,13$ & $21,83 \%$ & $4,48 \%$ \\
\hline MS & 2017 & $\mathrm{R} \$ 8.403 .302 .654,14$ & $\mathrm{R} \$ 2.814 .002 .513,11$ & $33,48 \%$ & $\mathrm{R} \$ 176.158 .310,61$ & $31,39 \%$ & $2,09 \%$ \\
\hline MG & 2017 & $\mathrm{R} \$ 47.208 .211 .179,15$ & $\mathrm{R} \$ 10.608 .245 .984,48$ & $22,47 \%$ & - & - & - \\
\hline PA & 2018 & $\mathrm{R} \$ 15.548 .461 .000,00$ & $\mathrm{R} \$ 4.100 .038 .000,00$ & $26,72 \%$ & - & - & - \\
\hline PB & 2015 & $\mathrm{R} \$ 7.618 .070 .000,00$ & $\mathrm{R} \$ 1.858 .978 .000,00$ & $24,40 \%$ & $\mathrm{R} \$ 243.766 .000,00$ & $21,20 \%$ & $3,20 \%$ \\
\hline PR & 2017 & $\mathrm{R} \$ 30.242 .417 .764,00$ & $\mathrm{R} \$ 10.870 .426 .633,00$ & $36,26 \%$ & - & - & - \\
\hline
\end{tabular}




\section{Tabela I - Dados sobre as receitas e despesas em MDE e despesas com inativos da educação - Valores nominais $(\mathbf{R} \$ 1,00)$}

\begin{tabular}{|c|c|c|c|c|c|c|c|}
\hline UF & Exc. Fin & Receita Liquida & MDE & \% MDE & $\begin{array}{c}\text { Despesas com } \\
\text { Inativos elou déficit } \\
\text { previdenciário }\end{array}$ & $\begin{array}{c}\% \text { da MDE } \\
\text { sem os } \\
\text { Inativos }\end{array}$ & $\begin{array}{c}\text { Diferença } \\
\text { dos \% }\end{array}$ \\
\hline $\mathrm{PE}$ & 2017 & $\mathrm{R} \$ 18.566 .380 .328,61$ & $\mathrm{R} \$ 5.104 .231 .236,37$ & $27,49 \%$ & $\mathrm{R} \$ 799.583 .795,71$ & $23,19 \%$ & $4,30 \%$ \\
\hline $\mathrm{PI}$ & 2017 & $\mathrm{R} \$ 6.242 .407 .745,36$ & $\mathrm{R} \$ 1.579 .029 .021,99$ & $25,30 \%$ & - & - & - \\
\hline $\mathrm{RR}$ & 2018 & $\mathrm{R} \$ 2.979 .147 .038,93$ & $\mathrm{R} \$ 722.134 .591,92$ & $24,24 \%$ & - & - & - \\
\hline $\mathrm{RO}$ & 2016 & $\mathrm{R} \$ 5.382 .263 .751,20$ & $\mathrm{R} \$ 1.363 .101 .170,83$ & $25,33 \%$ & - & - & - \\
\hline $\mathrm{RJ}$ & 2017 & $\mathrm{R} \$ 37.756 .790 .651,00$ & $\mathrm{R} \$ 9.216 .382 .593,26$ & $24,41 \%$ & $\mathrm{R} \$ 3.472 .315 .675,00$ & $15,21 \%$ & $9,20 \%$ \\
\hline $\mathrm{RN}$ & 2016 & $\mathrm{R} \$ 7.920 .207 .153,43$ & $\mathrm{R} \$ 2.025 .344 .564,04$ & $25,57 \%$ & $\mathrm{R} \$ 55.566 .909,09$ & $24,90 \%$ & $0,67 \%$ \\
\hline $\mathrm{RS}$ & 2016 & $\mathrm{R} \$ 29.176 .000 .000,40$ & $\mathrm{R} \$ 7.362 .000 .000,50$ & $29,28 \%$ & $\mathrm{R} \$ 3.448 .000 .000,20$ & $13,42 \%$ & $15,86 \%$ \\
\hline $\mathrm{SC}$ & 2017 & $\mathrm{R} \$ 18.474 .407 .230,31$ & $\mathrm{R} \$ 4.973 .344 .549,24$ & $26,92 \%$ & $\mathrm{R} \$ 780.337 .339,31$ & $22,67 \%$ & $4,25 \%$ \\
\hline $\mathrm{SP}$ & 2017 & $\mathrm{R} \$ 118.558 .750 .000,00$ & $\mathrm{R} \$ 37.185 .894 .000,00$ & $31,36 \%$ & $\mathrm{R} \$ 7.248 .054 .000,00$ & $25,25 \%$ & $6,11 \%$ \\
\hline $\mathrm{SE}$ & 2017 & $\mathrm{R} \$ 6.242 .407 .745,32$ & $\mathrm{R} \$ 1.591 .823 .909,52$ & $25,50 \%$ & - & - & - \\
\hline $\mathrm{TO}$ & 2017 & $\mathrm{R} \$ 6.172 .732 .937,39$ & $\mathrm{R} \$ 1.552 .325 .192,09$ & $25,15 \%$ & - & - & - \\
\hline $\mathrm{UN} \mathrm{I} \mathrm{A} 0$ & 2018 & $\mathrm{R} \$ 272.116 .000 .000,00$ & $\mathrm{R} \$ 61.902 .223 .000,00$ & $22,07 \%$ & - & - & - \\
\hline
\end{tabular}

Fontes: Sites do Tribunais de Contas, da Contadorias estaduais, da Secretarias Estaduais de Planejamento, da Secretarias Estaduais da Fazenda, do Ministério Público Estadual de Contas, da transparência.

Tabela elaborada do autor.

É possível constatar que há de valores significativos da MDE que foram aplicados com as despesas de inativos e déficit previdenciário ou foram previstos para serem aplicados nessas despesas. Se a maioria dos entes federados não incluísse essa despesa não conseguiriam cumprir o percentual mínimo. Não foram encontrados dados detalhados acerca de inativos de alguns governos (AP, BA, CE, MG, PA, PR PI, RR, RO, SE, TO), o que não significa que não estejam aplicando recursos da MDE ou da educação em pagamento de inativos. Nos governos estaduais, cujas despesas com inativos não alcançaram 1\% (DF, MA e RN), pode indicar que as despesas se referem às contribuições patronais para a previdência, pois devem ser pagas com os recursos da MDE ou mesmo da educação.

Um caso alarmante se refere ao governo estadual do Rio Grande do Sul que, em 2016, pagou os inativos com recursos oriundos do Fundeb. O governo estadual utilizou $\mathrm{R} \$$ 1.378.000.000,30 do Fundeb para pagamento de inativos, segundo o Relatório do Parecer das Contas do TCE-RS (RIO GRANDE DO SUL, 2016). Nesse caso, a EC 53, de 2006, determina que 60\%, no mínimo, dos recursos do Fundeb sejam destinados ao pagamento dos profissionais do magistério da educação básica em efetivo exercício. Cabe destacar que inativos recebem provento e não salário, ou mesmo remuneração, além disso não estão em efetivo exercício no magistério, como determina a Lei do Fundeb. 
Outro fato importante, revelado neste artigo, se refere aos entes que, mesmo não aplicando o percentual mínimo previsto na $\mathrm{CF} / 88$, ainda aplicaram significativos recursos na despesa com inativos, como foi o caso dos governos do GO, PB e RJ. Muitos entes federados "escondem" os gastos com inativos em categorias econômicas genéricas, por exemplo, as despesas administrativas, e com isso fica impossível constatar o volume de recursos aplicados com inativos. Com relação à União, a Controladoria-Geral da União apresentou um estudo, em 2019, alegando ter retirado das despesas com MDE os inativos, mas foi omisso ao falar se as despesas foram computadas na educação, haja vista que estavam previstas na LOA para o exercício de 2018 como previsão de despesa em educação pagas com recursos da fonte 100 (recursos próprios), totalizando mais de $\mathrm{R} \$ 14$ bilhões (BRASIL, 2019c). A elevada despesa com inativos sempre esteve presente no MEC. Segundo pesquisa realizada sobre as despesas do MEC, na década de 1990, constatou-se que a despesa com inativos cresceu significativamente nesse período, chegando a ser a segunda maior despesa do Ministério, em 1999 (RIBEIRO, 2001).

Com relação aos gastos com inativos no ensino de Instituições Federais de Ensino Superior (IFES), o ex-reitor da Universidade Federal do Rio de Janeiro (UFRJ), Roberto Leher, afirmou, em entrevista, que uma possível saída para os entraves financeiros pelos quais passa a universidade pública brasileira "seria o MEC ficar com a responsabilidade de pagar (os inativos), e a origem dessa rubrica entrar na conta da Previdência" (O GLOBO, 2018).

Além disso, o ex-reitor afirmou que a contabilização dos inativos na educação destoa das metodologias de referência como a adotada pela Organização para a Cooperação e Desenvolvimento Econômico (OCDE). Essa manobra, por sua vez, avoluma o montante de recursos aplicados em educação e nos aproxima da média dos países da OCDE no que tange ao percentual do Produto Interno Bruto (PIB) na educação. Contudo, não representa a realidade das condições materiais das escolas brasileiras, pois, como foi dito, parte desses recursos não chega onde deveria chegar.

Para compreender os efeitos dos gastos com inativos da educação das redes estaduais e federal de ensino, foi elaborada a Tabela II, que apresenta na primeira coluna a relação dos estados que utilizam recursos da MDE com pagamento dos inativos; na segunda coluna, os valores aplicados com inativos; na terceira, o valor aluno ano Fundeb, retirado da Portaria Interministerial 7/2018 do MEC/FNDE, para matrículas no ensino fundamental integral e no ensino médio integral por estado; na quarta, o quantitativo de matrículas que os recursos com 
inativos poderiam financiar; na quinta, o quantitativo de pessoas de 6 a 17 anos de idade fora da escola; e, na sexta, os valores que sobrariam após a universalização da área de atuação prioritária dos estados.

\section{Tabela II - Aplicação dos recursos com inativos para universalizar a educação nos estados}

\begin{tabular}{|c|c|c|c|c|c|}
\hline UF & $\begin{array}{l}\text { VALORES GASTOS } \\
\text { COM INATIVOS (A) }\end{array}$ & $\begin{array}{l}\text { VALOR ALUNO ANO } \\
\text { FUNDEB (ENSINO } \\
\text { FUNDAMENTAL E } \\
\text { MÉDIO INTEGRAL) (B) }\end{array}$ & $\begin{array}{c}\text { MATRÍCULAS } \\
\text { COM RECURSOS } \\
\text { DOS INATIVOS } \\
(A: B=C)\end{array}$ & $\begin{array}{l}\text { JOVENS DE } 6 \text { A } \\
17 \text { ANOS FORA } \\
\text { DA ESCOLA (D) }\end{array}$ & $\begin{array}{c}\text { RECURSOS QUE } \\
\text { SOBRARIAM APÓS } \\
\text { UNIVERSALIZAÇÃO } \\
\text { DAS MATRÍCULAS } \\
\text { (C-DxB=E) }\end{array}$ \\
\hline$A C$ & $\mathrm{R} \$ 171.315 .193,93$ & $\mathrm{R} \$ 4.612,50$ & 37.142 & 16.467 & $R \$ 95.361 .156,43$ \\
\hline $\mathrm{AL}$ & $\mathrm{R} \$ 369.900 .495,00$ & $\mathrm{R} \$ 4.210,08$ & 87.861 & 48.450 & $\mathrm{R} \$ 165.922 .119,00$ \\
\hline AM & $\mathrm{R} \$ 934.763 .000,00$ & $\mathrm{R} \$ 5.420,90$ & 172.437 & 59.235 & $\mathrm{R} \$ 613.655 .988,50$ \\
\hline DF & $\mathrm{R} \$ 1.084 .479,00$ & $\mathrm{R} \$ 5.175,39$ & 210 & 17.200 & $-\mathrm{R} \$ 87.932 .229,00$ \\
\hline ES & $\mathrm{R} \$ 717.958 .661,60$ & $\mathrm{R} \$ 4.497,40$ & 159.639 & 37.181 & $\mathrm{R} \$ 550.740 .832,20$ \\
\hline GO & $\mathrm{R} \$ 1.535 .046 .209,00$ & $\mathrm{R} \$ 4.728,84$ & 324.614 & 65.558 & $\mathrm{R} \$ 1.225 .032 .916,28$ \\
\hline MA & $R \$ 25.963 .385,52$ & $\mathrm{R} \$ 4.210,08$ & 6.167 & 95.455 & -R\$ $375.909 .800,88$ \\
\hline MT & $\mathrm{R} \$ 423.337 .677,13$ & $\mathrm{R} \$ 4.445,18$ & 95.235 & 38.097 & $\mathrm{R} \$ 253.989 .654,67$ \\
\hline MS & $\mathrm{R} \$ 176.158 .310,61$ & $\mathrm{R} \$ 4.818,61$ & 36.558 & 31.813 & $\mathrm{R} \$ 22.863 .870,68$ \\
\hline PB & $\mathrm{R} \$ 243.766 .000,00$ & $\mathrm{R} \$ 4.210,08$ & 57.901 & 49.131 & $\mathrm{R} \$ 36.920 .559,52$ \\
\hline $\mathrm{PE}$ & $\mathrm{R} \$ 799.583 .795,71$ & $\mathrm{R} \$ 4.762,67$ & 167.886 & 122.614 & $\mathrm{R} \$ 215.613 .776,33$ \\
\hline RJ & $\mathrm{R} \$ 3.472 .315 .675,00$ & $\mathrm{R} \$ 4.828,03$ & 719.199 & 98.825 & $\mathrm{R} \$ 2.995 .185 .610,25$ \\
\hline RN & $\mathrm{R} \$ 55.566 .909,09$ & $\mathrm{R} \$ 6.355,67$ & 8.743 & 39.562 & -R\$ 195.876.107,45 \\
\hline RS & $\mathrm{R} \$ 3.448 .000 .000,20$ & $\mathrm{R} \$ 5.558,05$ & 620.361 & 100.196 & $\mathrm{R} \$ 2.891 .105 .622,40$ \\
\hline SC & $\mathrm{R} \$ 1.730 .000 .000,00$ & $\mathrm{R} \$ 4.957,04$ & 348.999 & 52.309 & $\mathrm{R} \$ 1.470 .702 .194,64$ \\
\hline SP & $\mathrm{R} \$ 7.194 .553 .000,00$ & $\mathrm{R} \$ 4.989,83$ & 1.441 .843 & 324.307 & $\mathrm{R} \$ 5.576 .316 .202,19$ \\
\hline
\end{tabular}

Fontes: Portaria Interministerial 7, de 28 de dezembro de 2018. Sites dos Tribunais de Contas. PNAD Contínua 2015. Tabela elaborada pelo autor.

Os dados revelam que os estados e o DF poderiam universalizar o ensino fundamental e o médio, em tempo integral, alcançando assim as metas previstas na Lei do PNE (Lei federal 13.005/2014) para essas etapas da educação básica. Além disso, sobrariam recursos volumosos para investir em outras despesas da MDE, tal como a infraestrutura das unidades escolares. No caso da União, os R \$ 14 bilhões previstos na LOA para pagar inativos poderiam custear 373 mil vagas no ensino superior, considerando um custo aluno ano de $\mathrm{R} \$ 37.551,00$ (BRASIL, 2018c; 2019a; 2019c). Isso contribuiria para o alcance da meta 12 do PNE, que determina que, até $2024,33 \%$ das pessoas entre 18 e 24 devam estar matriculadas no ensino superior. 
Indo além, pode-se constatar, através do Censo Escolar 2018, que muitas unidades escolares públicas não contam com bibliotecas; sala de leitura; refeitório; saneamento básico; acessibilidade; laboratório de ciências; quadra de esportes; professores bem remunerados e com plano de carreira; gestão democrática; entre outros fatores que influenciam diretamente para a melhoria do ensino no país (BRASIL, 2018b). Além disso, ao sair da frieza dos números, é de estarrecer que os governos apliquem tantos recursos em uma despesa questionável, como a com inativos, tendo, segundo o Indicador de Analfabetismo Funcional (Inaf), quase $30 \%$ da população classificada como analfabeta funcional, o que denota que a qualidade do ensino das escolas públicas precisa melhorar bastante (ARTES, 2007).

Atualmente o debate acerca do Fundeb Permanente ou "Novo Fundeb" tem caminhado para colocar um ponto final nas discussões do custeamento de despesas com inativos na educação, pois a PEC 15-A de 2015, apresentada em 2019, propõe que os recursos da MDE e do Salário-Educação não possam ser aplicados para pagamento de aposentadorias e pensões (BRASIL, 2015). Analisando a história de proposições que tentaram impedir esse gasto, pode-se concluir que será muito difícil que a supracitada PEC seja aprovada com essa proibição. Contudo, é importante tensionar o governo, no âmbito do Congresso, para que essa despesa seja por força constitucional proibida. Caso contrário, a educação pública continuará perdendo bilhões de reais ano após ano com essa despesa, que, sem dúvida, é inadequada quando paga pelos recursos da educação.

\section{ASPECTOS CONCLUSIVOS}

Não é objetivo da presente pesquisa esgotar a discussão acerca do pagamento de inativos da educação com recursos da educação. O objetivo é justamente tentar colocar o debate no centro das discussões acerca da previdência e do financiamento da educação no país. É notório que o recrudescimento das políticas ultraconservadoras, apoiadas na ideologia neoliberal nos últimos anos tem trazido à tona uma agenda internacional de contrarreformas que visam, precipuamente, à desconstrução de direitos sociais consolidados, sobretudo através da luta de classes no país. Sendo assim, a importância de analisar profundamente as políticas sociais se faz permanente, principalmente, para defendê-las das ofensivas da classe dominante.

Desde a década de 1980, políticos, educadores, pesquisadores, movimentos sociais, movimentos a favor da educação pública, gratuita, laica e de qualidade têm discutido se os inativos devem compor ou não o rol de despesas na educação. 
Muitos governos têm aproveitado brechas legais e a judicialização da questão para continuar aplicando volumosos recursos da educação nessas despesas. Na mesma proporção tais recursos deixam de atender às redes de ensino.

A discussão dos inativos da educação atravessa o tema da vinculação constitucional de percentual mínimo de impostos na MDE, pois para cumprilo os governos recorrem pagar os inativos. Com isso, além de não resolverem o entrave atuarial da previdência, os governos deixam de aplicar significativos recursos na MDE, que possibilitaria, por exemplo, a universalização da educação no país e a melhoria das redes públicas de ensino. Essa manobra pode esconder, também, a corrupção dos recursos que são contabilizados duplamente nessa despesa.

Um aspecto importante se refere à função dos Tribunais de Contas e do Poder Legislativo no sentido de fiscalizar as contas dos entes federados. Como ficou constatado neste artigo, muitos Tribunais têm sido coniventes com a inclusão de inativos nas despesas com educação mesmo considerando-a indevida. Destacam-se também os esforços do Poder Judiciário que, através dos Ministérios Públicos de Contas, têm, em sua maioria, se posicionado contra a inclusão dessa despesa na educação, elaborando pareceres bem consistentes e rigorosos acerca desse tema. Contudo, mesmo aqueles Tribunais mais rigorosos na análise das contas veem seus esforços frustrados com a aprovação das contas no âmbito das Casas Legislativas que consideram os aspectos políticos mais do que técnicos ao votarem as contas do Executivo.

Por fim, é necessário compreender os meandros do financiamento da educação brasileira, sobretudo para não cair no lugar comum dos discursos que tentam cristalizar um senso comum de classe ao afirmar que o país gasta muito com educação. Mesmo entendendo a complexidade da luta de classes no atual panorama político, econômico, social e histórico, é necessário atuar com base naquilo que Coutinho (1992) designou como "reformismo revolucionário", enquanto caminho mais adequado para a luta pelo socialismo no Brasil. Desse modo, é fundamental compreender a realidade da função e das finalidades dos recursos da educação e tensionar os governos para que os apliquem devidamente em sua finalidade, sobretudo para arrefecer o recrudescimento do processo privatizante e a consequente desconstrução da educação pública, gratuita, laica e de qualidade. 


\section{REFERÊNCIAS}

ALAGOAS. Ministério Público de Contas. Relatório das Contas do Governo do Exercício de 2011. Maceió, 2011. Disponível em: <http://www.mpc.al.gov. br/wp-content/uploads/2016/12/Parecer-MPC-2-Contas-do-Governo-doEstado-20111.pdf>. Acesso em: 22 de abr. de 2019.

ARTES, Amélia Cristina. Indicador nacional de alfabetismo funcional - 2001: explorando as diferenças entre mulheres e homens. Educação e Pesquisa, São Paulo, v. 33, n. 3, p. 561-580, 2007.

BASSI, Marcos Edgar; VERÇOSA, Pelegrino Santos. O financiamento da educação básica no estado do Acre/Br: um estudo da vinculação da receita de impostos. Revista on-line de Política e Gestão Educacional, Araraquara, v. 21, n. 2, p. 303-321, 2017.

BRASIL. Constituição da República Federativa do Brasil. Diário Oficial da União, Brasília, DF, 05 out. 1988. Disponível em: <http://www.planalto.gov.br/ ccivil_03/constituicao/constituicao.htm>. Acesso em: 8 abr. 2019.

Emenda Constitucional n. 24, de $1^{\circ}$ de dezembro de 1983. Estabelece a obrigatoriedade de aplicação anual, pela União, de nunca menos de treze por cento, e pelos Estados, Distrito Federal e Municípios, de, no mínimo, vinte e cinco por cento da renda resultante dos impostos, na manutenção e desenvolvimento do ensino. Diário Oficial da União, Brasília, DF, 5 dez. 1983. Disponível em: <http://www.planalto.gov.br>. Acesso em: 10 jun. 2019.

Emenda Constitucional n. 95, de 15 de dezembro de 2016. Altera o Ato das Disposições Constitucionais Transitórias, para instituir o Novo Regime Fiscal, e dá outras providências. Diário Oficial da União, Brasília, DF, 15 dez. 2016a. Disponível em: <http://www.planalto.gov.br/ccivil_03/constituicao/Emendas/ Emc/emc95.htm>. Acesso em: 8 abr. 2019.

Emenda Constitucional n. 14, de 12 de setembro de 1996. Modifica os arts. 34, 208, 211 e 212 da Constituição Federal e dá nova redação ao art. 60 do Ato das Disposições Constitucionais Transitórias. Diário Oficial da União, Brasília, DF, 13 set. 1996b. Disponível em: < http://www.planalto.gov. br/ccivil_03/constituicao/emendas/emc/emc14.htm>. Acesso em: 8 jan. 2016. 
. Emenda Constitucional n. 53, de 19 de dezembro de 2006. Dá nova redação aos arts. $7^{\circ}, 23,30,206,208,211$ e 212 da Constituição Federal e ao art. 60 do Ato das Disposições Constitucionais Transitórias. Diário Oficial da União, Brasília, DF, 20 dez. 2006. Disponível em: <http://www.planalto.gov.br/ ccivil_03/constituicao/Emendas/Emc/emc53.htm>. Acesso em: 8 jan. 2016.

- Câmara dos Deputados. Proposta de Emenda à Constituição n. 15-A de 07 de abril de 2015. Insere parágrafo único no art. 193; inciso IX, no art. 206 e art. 212-A, todos na Constituição Federal, de forma a tornar o Fundo de Manutenção e Desenvolvimento da Educação Básica e de Valorização dos Profissionais da Educação - Fundeb instrumento permanente de financiamento da educação básica pública, incluir o planejamento na ordem social e inserir novo princípio no rol daqueles com base nos quais a educação será ministrada, e revoga o art. 60 do Ato das Disposições Constitucionais Transitórias. Diário Oficial da União, Brasília, DF, 7 abr. 2015. Disponível em: <https://www.camara.leg.br/ proposicoesWeb $/$ fichadetramitacao?idProposicao $=1198512>$. Acesso em: 8 abr. 2019.

. Medida Provisória no 339, de 28 de dezembro de 2006. Regulamenta o art. 60 do Ato das Disposições Constitucionais Transitórias e dá outras providências. Diário Oficial da União, Brasília, DF, 29 dez. 2006.

BRASIL. Lei no 7.348, de 24 de julho de 1985. Dispõe sobre a execução do $\int 4^{\circ}$ do art. 176 da Constituição Federal, e dá outras providências. Diário Oficial da União, Brasília, DF, 24 jul. 1985. Disponível em: <http://www.planalto.gov.br/ ccivil_03/LEIS/1980-1988/L7348.htm>. Acesso em: 8 abr. 2019.

. Lei n ${ }^{\circ}$ 9.394, de 20 de dezembro de 1996a. Lei de Diretrizes e Bases da Educação Nacional. Diário Oficial da União, Brasília, DF, 24 dez. 1996. Disponível em: < http://www.planalto.gov.br/ccivil_03/leis/19394.htm>. Acesso em: 8 abr. 2019.

. Lei $\mathrm{n}^{\circ}$ 9.424, de 24 de dezembro de 1996b. Dispõe sobre o Fundo de Manutenção e Desenvolvimento do Ensino Fundamental e de Valorização do Magistério, na forma prevista no artigo $60 \int 7^{\circ}$, do Ato das Disposições Constitucionais Transitórias, e dá outras providências. Brasília: Diário Oficial da União, Brasília, 26 dez. 1996. 
Lei n. 10.172, de 9 de janeiro de 2001. Aprova o Plano Nacional de Educação e dá outras providências. Diário Oficial da União, Brasília, DF, 10 jan. 2001. Disponível em: <http://www.planalto.gov.br/ccivil_03/leis/leis_2001/ 110172.htm>. Acesso em: 8 jan. 2016.

. Lei no 11.494, de 20 de junho de 2007. Dispõe sobre o Fundo de Manutenção e Desenvolvimento da Educação Básica e de Valorização dos Profissionais da Educação, na forma prevista no artigo $60 \$ 7^{\circ}$, do Ato das Disposições Constitucionais Transitórias, e dá outras providências. Brasília: Diário Oficial da União, Brasília, 20 jun. 2007a.

Câmara dos Deputados. Projeto de lei n. 1258, de 28 de novembro de 1988. Fixa Diretrizes e Bases da Educação Nacional. Diário Oficial da União, Brasília, DF, 28 nov. 1988. Disponível em: < https://www.camara.leg.br/ proposicoesWeb/fichadetramitacao?idProposicao=189757>. Acesso em: 8 abr. 2019.

Câmara dos Deputados. Projeto de lei n. 4504, de 16 de outubro de 1984. Dispõe sobre a execução do parágrafo quarto do artigo 176 da Constituição Federal e dá outras providências. Diário Oficial da União, Brasília, DF, 16 out. 1984. Disponível em: <https://www.camara.leg.br/proposicoesWeb/fichadetra mitacao?idProposicao=222071>. Acesso em: 8 abr. 2019.

Câmara dos Deputados. Projeto de lei n. 4155, de 10 de fevereiro de 1998. Aprova o Plano Nacional de Educação. Diário Oficial da União, Brasília, DF, 10 fev. 1998. Disponível em: <https://www.camara.leg.br/proposicoesWeb/ fichadetramitacao?idProposicao=222071>. Acesso em: 08 abr. 2019.

Supremo Tribunal Federal. Ação Direta de Inconstitucionalidade n. 282. Relator Ministro Sydney Sanches. Brasília, DF, 1990.

. Supremo Tribunal Federal. Ação Direta de Inconstitucionalidade n. 4102. Relator Ministra Cármen Lúcia. Brasília, DF, 2014.

BRASIL. Supremo Tribunal Federal. Ação Direta de Inconstitucionalidade n. 5546. Relator Ministro Roberto Barroso. Brasília, DF, 2016b. . Supremo Tribunal Federal. Ação Direta de Inconstitucionalidade n. 5719. Relator Ministro Edson Fachin. Brasília, DF, 2017 a. 
. Supremo Tribunal Federal. Ação Direta de Inconstitucionalidade n. 5691. Relator Ministro Rosa Weber. Brasília, DF, 2017b.

. Supremo Tribunal Federal. Ação Direta de Inconstitucionalidade n. 6049. Relator Ministro Ricardo Lewandowski. Brasília, DF, 2018a.

- Ministério da Educação e do Desporto. Conselho Nacional da Educação. Financiamento da Educação na Lei 9.394, de 1996. Parecer CP n. 026/97 aprovado em 2 de dezembro de 1997. Relator: Almir Maia, Jacques Velloso, João Monlevade e Silke Weber. Brasília, DF, 1997. Disponível em: < http://portal.mec. gov.br/cne/arquivos/pdf/PNCP2697.pdf> Acesso em: 25 de jul. 2019.

. Ministério da Educação. Perguntas Frequentes (Fundeb). BrasíliaDF, 2008. Disponível em: <https://www.fnde.gov.br/index.php/centrais-deconteudos/publicacoes / category/167-fundeb?download=6192:versao-paraimpressao $>$. Acesso em 8 ago. 2019.

Ministério da Educação. EDUCACENSO 2018. Brasília-DF, 2018b. Disponível em: <http://www.educacenso.inep.gov.br/censobasico/>. Acesso em 8 ago. 2019.

Ministério da Educação. Nota Técnica MEC/SE, n. 4, de 22 de fevereiro de 2018. Brasília-DF, 2018c. Disponível em: <http://forplad. andifes.org.br/sites/default/files/forplad/comissaoplanejamento/NT_042018_e_anexos_-_apura\%C3\%A7\%C3\%A3o_do_custo_das_universidades. pdf?fbclid=IwAR01 iflDrvQKU-4S0y5XWVVR9EIOijeE4SKq-LE_ oCYH9oqfXt0Gfh1jsvQ>. Acesso em: 20 de set. 2019.

Controladoria-Geral da União. Cartilha Olho Vivo no Dinheiro

Público. Um guia para o cidadão garantir os seus direitos. Brasília, DF. 2012. Disponível em: <http://www.mc.gov.br/doccrs/doc_download/1447-cartilhaolho-vivo-no-dinheiro-publico-um-guia-para-o-cidadaogarantir-seus-direitos $>$. Acesso em: 9 de abr. 2019.

. Secretaria do Tesouro Nacional. Anexo de metas fiscais e relatório resumido da execução orçamentária: manual de elaboração aplicado à União, aos Estados, Distrito Federal e Municípios. 7. ed. atual. Brasília: STN, 2007b. 
Secretaria do Tesouro Nacional. Anexo de metas fiscais e relatório resumido da execução orçamentária: manual de elaboração aplicado à União, aos Estados, Distrito Federal e Municípios. 8. ed. atual. Brasília: STN, 2018d.

BRASIL. Controladoria Geral da União. Prestação de Contas do Presidente da República 2018. Brasilia-DF, 2019a. Disponível em: < https://www.cgu.gov. br/assuntos/auditoria-e-fiscalizacao/avaliacao-da-gestao-dos-administradores/ prestacao-de-contas-do-presidente-da republica/arquivos/2018/pcpr-2018. pdf $>$. Acesso em: 14 de jun. 2019.

Tribunal de Contas da União. Acórdão n. 1656. Brasília-DF, 2019b. Levantamento. Estrutura de financiamento da educação no Brasil. Produção de conhecimento destinado a subsidiar futuras ações de controle externo. Brasília, DF. 2019. Disponível em: < https:/ / portal.tcu.gov.br/inicio/>. Acesso em: 9 abr. 2019.

. Ministério do Planejamento, Desenvolvimento e Gestão. Lei $\mathbf{n}^{\mathbf{0}} \mathbf{1 3 8 0 8}$, de 15 de janeiro de 2019. LOA 2019c. Brasília-DF, 2019. Disponível em: < http:/ / www.planejamento.gov.br/assuntos/orcamento-1/orcamentos-anuais/2019/ loa-2019/lei-no-13808-de-15-de-janeiro-de-2019-loa-2019.pdf/view>. Acesso em: 13 de jun. 2019.

. Câmara Federal. Discurso proferido pelo deputado Mauro Benevides

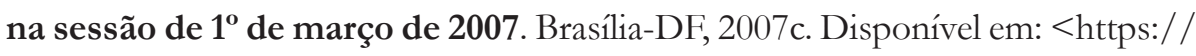
www.camara.leg.br > proposicoesWeb > prop_mostrarintegra >. Acesso em: 12 jun. 2019.

CASTRO, Jorge Abrahão de. Financiamento da educação no Brasil. Em aberto, Brasília, v. 18, n. 74, 2008.

BALEEIRO, A. O Supremo Tribunal Federal, esse outro desconhecido. Rio de Janeiro, Forense, 1968.

COUTINHO, Carlos Nelson. Democracia e socialismo. Questões de princípio e contexto brasileiro. São Paulo: Cortez, 1992.

DAVIES, Nicholas. Tribunais de contas e os seus procedimentos de verificação dos recursos da educação. Revista Brasileira de Política e Administração da Educação, v. 19, n. 1, p. 99-115, 2003. 
DAVIES, Nicholas. O financiamento da educação estatal no Brasil: novos ou velhos desafios. Revista Educação On-line PUC-Rio, Rio de Janeiro, n. 10, p. 31-63, 2012.

DAVIES, Nicholas. A aplicação das verbas da educação: controle estatal ou social? In: GOUVEIA, Andréa Barbosa; PINTO, José Marcelino Rezende; CORBUCCI, Paulo Roberto. (Orgs.). Federalismo e políticas educacionais na efetivação do direito à educação no Brasil. Brasília: Ipea, 2011.

ESPÍRITO SANTO. Ministério Público de Contas do Estado do Espírito Santo. Relatório das Contas do Governo do Estado do Espírito Santo do Exercício de 2018. Disponível em: <https://www.mpc.es.gov.br/2019/06/ministeriopublico-de-contas-apresenta-parecer-sobre-as-contas-de-2018-de-governador $/>$. Acesso em 13 de jun. de 2019.

GOIÁS. Tribunal de Contas do Estado de Goiás. Relatório das Contas do Governo do Estado de Goiás do Exercício de 2008. Disponível em: < https:/ / portal.tce.go.gov.br/contas-do-governador>. Acesso em: 18 jun. 2019.

LOURENÇO, Edvânia Ângela de Souza; LACAZ, Francisco Antônio de Castro; GOULART, Patrícia Martins. Crise do capital e o desmonte da previdência social no Brasil. Serv. soc. soc, São Paulo, n. 130, p. 467-486, 2017.

MENEZES, Janaina S. S. A vinculação Constitucional de Recursos para a Educação: os (des)caminhos do ordenamento constitucional. Revista HISTEDBR Online, Campinas, n. 30, p. 149-163, 2008.

MINAS GERAIS. Tribunal de Contas do Estado de Minas Gerais. Instrução Normativa n. 02, de 1991. Disponível em: < https://www.tce.mg.gov.br/ Noticia/Detalhe/27>. Acesso em: 25 de abr. de 2019.

. Tribunal de Contas do Estado de Minas Gerais. Instrução Normativa n. 02, de 1997. Disponível em: < https://www.tce.mg.gov.br/Noticia/Detalhe/27>. Acesso em: 25 de abr. de 2019.

. Tribunal de Contas do Estado de Minas Gerais. Instrução Normativa n. 01, de 1999. Disponível em: < https://www.tce.mg.gov.br/Noticia/Detalhe/27>. Acesso em: 25 de abr. de 2019. 
. Tribunal de Contas do Estado de Minas Gerais. Instrução Normativa

n. 02, de 2002. Disponível em: < https://www.tce.mg.gov.br/Noticia/ Detalhe/27>. Acesso em: 25 de abr. de 2019.

. Tribunal de Contas do Estado de Minas Gerais. Instrução Normativa

n. 08, de 2004. Disponível em: < https://www.tce.mg.gov.br/Noticia/ Detalhe/27>. Acesso em: 25 de abr. de 2019.

Tribunal de Contas do Estado de Minas Gerais. Instrução Normativa n. 03, de 2007a. Disponível em: < https://www.tce.mg.gov.br/Noticia/ Detalhe/27>. Acesso em: 25 de abr. de 2019.

. Tribunal de Contas do Estado de Minas Gerais. Instrução Normativa

n. 06, de 2007b. Disponível em: < https://www.tce.mg.gov.br/Noticia/ Detalhe/27>. Acesso em: 25 de abr. de 2019.

MINAS GERAIS. Tribunal de Contas do Estado de Minas Gerais. Instrução Normativa n. 13, de 2008. Disponível em: < https://www.tce.mg.gov.br/ Noticia/Detalhe/27>. Acesso em: 25 de abr. de 2019.

. Tribunal de Contas do Estado de Minas Gerais. Instrução Normativa n. 01, de 2010. Disponível em: < https://www.tce.mg.gov.br/Noticia/Detalhe/27>. Acesso em: 25 de abr. de 2019.

. Tribunal de Contas do Estado de Minas Gerais. Instrução Normativa n. 09, de 2011a. Disponível em: < https://www.tce.mg.gov.br/Noticia/ Detalhe/27>. Acesso em: 25 de abr. de 2019.

. Tribunal de Contas do Estado de Minas Gerais. Instrução Normativa n. 12, de 2011b. Disponível em: < https://www.tce.mg.gov.br/Noticia/ Detalhe/27>. Acesso em: 25 de abr. de 2019.

. Tribunal de Contas do Estado de Minas Gerais. Instrução Normativa n. 05, de 2012. Disponível em: < https://www.tce.mg.gov.br/Noticia/Detalhe/27> . Acesso em: 25 de abr. de 2019. 
. Tribunal de Contas do Estado de Minas Gerais. Consulta n. 804606. Relator: Eduardo Carone Costa. Data: 6/7/2011. Assunto: Despesas com inativos e pensionistas. Belo Horizonte, 2011c. Disponível em: < file://C:/Users/win/ Downloads/Documento_95650.pdf>. Acesso em: 11 jul. 2019.

O GLOBO. UFRJ tem alto gasto com inativos, de acordo com Ministério da Educação. Publicada em 07/09/2018. Disponível em: <https://oglobo. globo.com/rio/ufrj-tem-alto-gasto-com-inativos-de-acordo-com-ministerio-daeducacao-23048128>. Acesso em: 18 jun. 2019.

PERNAMBUCO. Tribunal de Contas do Estado de Pernambuco. Resolução n. 14, de 12 de setembro de 2001. Estabelece normas para apresentação as prestações de contas dos recursos do FUNDEF pelos Municípios e dá outras providências. Recife, 2001. Disponível em: <http://www4.tce.pe.gov.br/ resolucao-virtual/2001/r142001.htm>. Acesso em: 11 jun. 2019.

PINTO, José Marcelino de Rezende. Os números do financiamento da educação no Brasil. Pro-posições, Campinas, v. 16, n. 3, p. 75-86, 2005.

RIBEIRO, José Aparecido Carlos. Financiamento e gasto do Ministério da Educação nos anos 90. Em Aberto, Brasília, v. 18, n. 74, 2001.

RIO DE JANEIRO (Estado). Tribunal de Contas do Estado do Rio de Janeiro. Relatório Técnico das Contas do Governo do Estado do Rio de Janeiro do Exercício de 2018. Disponível em: < https://www.tce.rj.gov.br/consultaprocesso/ >. Acesso em: 18 jun. 2019.

RIO DE JANEIRO (Município). Lei n. ${ }^{\circ}$ 5.300, de 13 de setembro de 2011. Dispõe sobre o Plano de Capitalização do FUNPREVI e dá outras providências. Disponível em: < http://mail.camara.rj.gov.br/APL/Legislativos/contlei.nsf/c8a a0900025feef6032564ec0060dfff/49ccc3edf4ccca1b8325790b006789ce?OpenD ocument>. Acesso em: 13 de jun. 2019.

RIO DE JANEIRO (Município). Tribunal de Contas do Município do Rio de Janeiro. Relatório das Contas do Governo do Exercício de 2017 elaborado pela Coordenadoria de Auditoria e Desenvolvimento CAD-TCM. Disponível em: <http://www.tcm.rj.gov.br/Noticias/13396/2018-05-29_relatorio_CAD. pdf $>$. Acesso em: 13 de jun. 2019. 
RIO GRANDE DO SUL. Tribunal de Contas do Estado do Rio Grande do Sul. Relatório Técnico das Contas do Governo do Estado do Rio de Janeiro do Exercício de 2018. Disponível em:<http://www1.tce.rs.gov.br/portal/page/ portal/tcers/consultas/contas_estaduais/contas_governador>. Acesso em: 29 de ago. de 2019.

SANTA CATARINA. Tribunal de Contas do Estado de Santa Catarina. Relatório Técnico das Contas do Governo do Estado de Santa Catarina do Exercício de 2007. Disponível em: < http://www.tce.sc.gov.br/content/contasdo-estado-0>. Acesso em: 18 jun. 2019.

- Ministério Público de Contas do Estado de Santa Catarina. Relatório Técnico das Contas do Governo do Estado de Santa Catarina do Exercício de 2017. Disponível em: <www.mpc.sc.gov.br > index.php > component > docman >doc_download >. Acesso em: 18 jun. 2019.

SÃO PAULO (Estado). Assembleia Legislativa do Estado de São Paulo. Comissão Parlamentar de Inquérito da Educação. São Paulo-SP, 1999. Disponível em: $<$ https://www.al.sp.gov.br/alesp/cpi/?idComissao=99982>. Acesso em $13 \mathrm{de}$ jun. 2019.

SÃO PAUlO (Estado). Ministério Público de Contas do Estado de São Paulo. Relatório das Contas do Governo do Estado de São Paulo do Exercício de 2018. Disponível em: <http://www.mpc.sp.gov.br/wp-content/ uploads/2019/05/Contas-do-Governador-2018.-TC-6453.989.18-8.-ParecerMPC.pdf>. Acesso em: 13 de jun. de 2019.

SÃO PAULO (Município). Lei $\mathbf{n}^{\mathbf{0}} \mathbf{1 3 . 2 4 5 ,} 26$ de dezembro de 2001. Define as despesas que poderão ser consideradas no cômputo do percentual das receitas destinado à educação, nos termos dos artigos 200, 203 e 208 da lei orgânica do município de São Paulo. Disponível em: < https:/ / leismunicipais.com.br/> Acesso em: 12 de ago. 2019.

SÃO PAULO (Município). Lei n. 15.963, de 15 de janeiro de 2014. Acrescenta referências à escala de padrões de vencimentos do quadro do magistério municipal, do quadro dos profissionais de educação - QPE. Disponível em: < https:// leismunicipais.com.br/>Acesso em: 12 de ago. 2019. 
SENA, Paulo. Financiamento da Educação e Receitas da União: Vinculação, Desvinculação e Re-Vinculação. Consultoria Legislativa da Câmara dos Deputados. Brasília/DF, 2009.

SOUZA, Fábio Araujo de. Governos de Goiás deixaram de aplicar R \$ 6,5 bilhões no ensino de 2000 a 2017. FINEDUCA - Revista de Financiamento da Educação, Porto Alegre, v. 8, p. 01-31, 2018.

VELlOSO, Jacques. A Emenda Calmon e os recursos da União. Cadernos de Pesquisa, São Paulo, v. 74, p. 20-39, 1990.

\section{ANEXO}

\begin{tabular}{|c|c|c|}
\hline UF & Exc. Fin. & Fonte \\
\hline$A C$ & 2016 & Lei n. 3.098 de 29 de dezembro de 2015 (LOA) e SIOPE \\
\hline AL & 2017 & $\begin{array}{l}\text { Lei n. 7.871, de } 19 \text { de janeiro de 2017. (LOA 2017) e Relatório Resumido da Execução Orçamentária (RREO } 6^{\circ} \\
\text { Bim.) }\end{array}$ \\
\hline AP & 2017 & Relatório Resumido da Execução Orçamentária (RREO $6^{\circ}$ Bim.) \\
\hline AM & 2016 & $\begin{array}{l}\text { Relatório e parecer prévio sobre a prestação de contas do governador do Estado do Amazonas, exercício de } \\
\text { 2016. TCE-AM e (LOA-2016) Lei n. 4.269, de } 15 \text { de dezembro de 2015, alterada pela Lei n. 4.411, de } 29 \text { de } \\
\text { dezembro de } 2016 \text {. }\end{array}$ \\
\hline $\mathrm{BA}$ & 2016 & Relatório e parecer prévio sobre a prestação de contas do governador do Estado da Bahia - 2016. \\
\hline CE & 2017 & $\begin{array}{l}\text { Parecer n. 4062/2018 - Procuradoria-Geral de contas e Relatório Anual das Contas do Governador - Exercício } \\
\text { de } 2017 \text { e Lei estadual n. 16.199, de } 29 \text { de dezembro de } 2016 .\end{array}$ \\
\hline DF & 2017 & $\begin{array}{l}\text { Lei n. 10.555 de } 29 \text { de dezembro de } 2016 \text { e SIOPE e RREO 6 BIM/2017 e MP de Contas Processo TC n. } \\
\text { 8298/2019-7 }\end{array}$ \\
\hline ES & 2017 & Parecer Prévio 00052/2018-1 \\
\hline GO & 2017 & Relatório Técnico de Contas do Governo - Exercício de 2017. \\
\hline MA & 2016 & RGF - Publicado D.O. em 24.01.2018, Edição 017 - Suplemento e RREO 6 Bim. \\
\hline MT & 2017 & $\begin{array}{l}\text { Parecer Prévio sobre as Contas MT do Processos n. 8.171-0/2018, 4.131-9/2017 e 8.019-5/2017 e LOA - Lei n. } \\
\text { 10.515, de } 26 \text { de janeiro de } 2017 .\end{array}$ \\
\hline MS & 2017 & 2017-LOA n. 4.976 de 29 de dez 2016 e Balanço Geral 2017 (SEFAZ) e Processo TC/MS:TC/2322/2018 \\
\hline MG & 2017 & Parecer de Contas - Processo n. 2018/50581-9 \\
\hline PA & 2018 & $\begin{array}{l}\text { Processo n. 2019/51266-0 e Parecer das Contas de Governo } 2018 \text { (MPC-PA) e Lei estadual n. } 8.587 \text { de } 28 \text { de } \\
\text { dezembro de } 2017 .\end{array}$ \\
\hline PB & 2015 & Processo TC 4533/16 Governo do Estado da Paraíba - Prestação de Contas Anuais 2015. \\
\hline PR & 2017 & $\begin{array}{l}\text { Relatório Final das Contas do Governo do PR pelo TCE-PR } 2017 \text { e Lei Estadual n. 18.948, de } 22 \text { de dezembro } \\
\text { de } 2016 \text { (LOA-2017). }\end{array}$ \\
\hline PE & 2017 & Balanço Geral 2017 VOL I TCE \\
\hline $\mathrm{PI}$ & 2017 & $\begin{array}{l}\text { Controladoria-Geral do Estado e CGE-Prestação de contas do governador do estado - exercício } 2015 \text { / } \\
\text { Protocolo: 006380/2016 }\end{array}$ \\
\hline $\mathrm{RR}$ & 2018 & Relatório da Controladoria-Geral sobre as Contas Anuais de Governo - Exercício 2017. \\
\hline RO & 2016 & $\begin{array}{l}\text { Relatório do Controle Interno sobre as Contas Anuais de Governo - Exercício } 2016 \text { e Lei n. 4.231, de } 28 \text { de } \\
\text { dezembro de } 2017 .\end{array}$ \\
\hline RJ & 2017 & Lei n. 7.514 LOA - 2017 Volume 1 e SIOPE \\
\hline
\end{tabular}




ANEXO
\begin{tabular}{|c|c|l|l|}
\hline UF & Exc. Fin. & \multicolumn{1}{|c|}{ Fonte } \\
\hline RN & 2016 & TCE-RN e Orçamento/2016 Lei n. 10.050 de 29/01/2016. \\
\hline RS & 2016 & Processo n. 005007-02.00/16-1 Parecer das Contas do Governo Estadual do RS e SIOPE. \\
\hline SC & 2017 & Relatório do Relator e Parecer Prévio sobre as Contas do Governo do Estado - Exercício de 2017. \\
\hline SP & 2017 & Processo n.: eTC-5198/989/16-2 e Parecer do MPE-SP \\
\hline SE & 2017 & Lei n. 8.170 de 21 de dezembro de 2016 (LOA 2017) e SIOPE \\
\hline TO & 2017 & Lei n. 3.177, de 28 de dezembro de 2016. (LOA 2017) e SIOPE \\
\hline BR & 2018 & $\begin{array}{l}\text { Brasil. Ministério do Planejamento, Desenvolvimento e Gestão. Secretaria de Orçamento Federal. Orçamentos } \\
\text { da União - exercício financeiro 2018: projeto de lei orçamentária. - Brasília, 2017. 6v. em 8 e PRESTAÇÃO DE } \\
\text { CONTAS DO PRESIDENTE DA REPUBLICA 2018. }\end{array}$ \\
\hline
\end{tabular}

FÁBIO ARAUJO DE SOUZA é Pós-doutor em Educação pela Universidade Federal de Goiás, doutor em Educação pela Universidade de São Paulo, mestre em Educação, Cultura e Comunicação nas periferias urbanas pela Universidade do Estado do Rio de Janeiro, pedagogo pela Universidade do Estado do Rio de Janeiro. Professor Adjunto da Faculdade de Educação da Universidade Federal do Rio de Janeiro.

E-mail: f.asouza@yahoo.com.br

Recebido em agosto de 2019

Aprovado em setembro de 2019 